\title{
Samuel da Rocha: escravo, aparentado, forro, carpinteiro e senhor (Porto feliz, São Paulo, século YIK)
}

Roberto Guedes*

Resumo: Abrangendo a cidade de Porto Feliz do século XIX, o trabalho analisa fragmentos da trajetória de vida do carpinteiro crioulo Samuel da Rocha, que passou mais de 25 anos em cativeiro. Mudou de senhor, ganhou a alforria e senhoreou um escravo, a quem também deu liberdade. Sem filhos, ele também foi filho, irmão, compadre, padrinho, esposo, isto é, envolvia-se em uma complexa rede parental, aspecto crucial para sua inserção social. Em testamento, deixou legados às irmandades de São Benedito e Nossa Senhora da Boa Morte, à Igreja de Nossa Senhora Mãe dos Homens, etc. Portanto, demonstra-se que nem sempre as clivagens entre escravidão e liberdade e a abordagem das devoções religiosas congeladas pela cor ou status jurídico contemplam as experiências sociais de indivíduos e grupos. Desse modo, analisar uma trajetória de vida propicia a percepção da fluidez das identidades sociais de indivíduos. Outrossim, abordar a amplitude das relações sociais do carpinteiro ajuda a compreender os mecanismos de exploração do trabalho, nos quais Samuel da Rocha atuou nas duas partes.

Palavras-chave: Escravidão. Liberdade. Carpinteiro.

Eu, Samuel da Rocha, achando-me doente, mas em meu prefeito juízo, faço meu testamento pela maneira seguinte.

* Professor do Departamento de Letras e Ciências Sociais da Universidade Federal Rural do Rio de Janeiro (UFRJ).E-mail: robguedes@superig.com.br. 
Declaro que sou católico [...] Declaro que sou natural desta cidade, filho de Domingos e Joana, já falecidos. Declaro que sou casado com Rosa de Arruda de cujo matrimônio não tivemos filhos algum, e não tendo por isso herdeiros necessários, instituo por minha única herdeira a dita minha mulher. Declaro que devo a minha comadre Cândida, escrava de Joaquim de Toledo, a quantia de 400 mil réis. Declaro que deixo liberto o meu escravo João com a condição dele pagar a dita minha comadre os 400 mil réis que lhe devo. Depois de efetuado o dito pagamento lhe será entregue a carta de liberdade. Declaro que deixo à Irmandade de São Benedito a quantia de 16 mil réis, e igual quantia à Irmandade Nossa Senhora da Boa Morte; e a mesma quantia para a Igreja de Nossa Senhora Mãe dos Homens. Declaro que quero que se me diga uma capela de missas por minha alma. Declaro que deixo a minha ferramenta de carpinteiro para o meu escravo João. Rogo queiram ser meus testamenteiros em primeiro lugar a minha mulher, em segundo o senhor Evaristo Rodrigues Leite, e em terceiro o senhor José Cardoso; e por essa forma dou por concluído este meu testamento que vai escrito e a meu rogo assinado por Maximiano José da Mota por eu não saber escrever. Porto Feliz, [19/04/1860]. ${ }^{1}$

O trabalho analisa fragmentos da trajetória de vida do carpinteiro crioulo Samuel da Rocha, que passou mais de 25 anos em cativeiro na cidade de Porto Feliz do século XIX, onde nasceu e de onde nunca deve ter saído, salvo talvez pelos municípios vizinhos do oeste paulista. ${ }^{2}$ Destino não incomum para escravos forros, ainda que muitos deles migrassem (FARIA, 1998; NADALIN, 2003), mudou de senhor, ganhou alforria e senhoreou um escravo, a quem deu liberdade condicional. Sem herdeiros, mas enraizado na vila, o negro Samuel da Rocha também foi filho, irmão, esposo, compadre, padrinho, isto é, envolveu-se em uma complexa rede parental, aspecto crucial para sua inserção social. Em suas vontades testamentais, deixou legados às Irmandades de São Benedito e Nossa Senhora da Boa Morte e à Igreja de Nossa Senhora Mãe dos Homens. Por estas últimas aspirações de Samuel da Rocha demonstrase que clivagens entre mundo da escravidão e mundo da liberdade, 
e segmentações de irmandades religiosas congeladas pela cor ou condição jurídico-social, ${ }^{3}$ não contemplam experiências sociais de indivíduos e grupos. Do mesmo modo, como se tem destacado, não cabem mais rígidas separações entre trabalho escravo e trabalho livre, dicotomias entre senhores e cativos, inclusive no âmbito familiar (GÓES, 2006, p. 545; GRAHAM, 2005, p. 59; MACHADO, 2008, cap. 4). Por exemplo, experiências no processo de trabalho perpassam estatutos jurídicos distintos (LIBBY; FURTADO, 2006). Outrossim, análises de trajetória de vida salientam a fluidez das identidades e das hierarquias sociais de personagens e famílias ao longo dos anos (REIS, 2008; XAVIER, 2008). Inspirados nestes estudos e na trajetória de vida do carpinteiro Samuel da Rocha, abordamos a exploração em uma sociedade escravista, na qual nosso personagem atuou nas duas partes. Para isso, usamos um corpo variado de fontes (listas nominativas de habitantes, inventários post-mortem, testamentos, registros paroquiais, etc), às quais o cruzamento de informações foi basilar.

Samuel deve ter nascido por volta de 1802, pois constava no domicílio do padre André da Rocha Abreu em 1803 com 2 anos de idade. ${ }^{4}$ Filho de Domingos e Joana, irmão de Domingos, Abraão e André, tornou-se enteado do crioulo Fortunato quando das segundas núpcias de sua mãe em outubro de $1817 .{ }^{5}$ Salvo seu pai africano mina, seus demais familiares eram crioulos nascidos em cativeiro. Foram familiarizados na escravidão, mas na escravidão do padre André da Rocha Abreu, vigário colado da vila, o que ajuda a entender os nomes bíblicos de parte da família, o nome do cativo André e ainda o sobrenome Rocha herdado, prática comum que os forros faziam questão de levar consigo a fim de desfrutarem do prestígio senhorial (GUEDES, 2008, cap. 5; SOARES, 2002) No caso dos parentes de Samuel, cujos homens usavam o sobrenome, a família de seu senhor era proeminente na vila desde meados do século XVIII, ocupando postos de oficiais das ordenanças, capitães-mores e capitães, por exemplo, mas também cargos eclesiásticos, vigários colados, chegando mesmo à vice-presidência da província de São Paulo do século XIX (GUEDES; GODOY, 2008; GODOY, 2002, cap. 4). 
Até cerca de seus 24 anos de idade, a maior parte dos escravos que Samuel conheceu era crioula. Entre 1798 e 1810-1815, a população escrava da vila experimentou uma reprodução natural que propiciou o crescimento vegetativo positivo, interrompido com o tráfico de escravos estimulado pela atividade açucareira. A proporção de cativos adultos (entre 14 e 45 anos) atesta essas mudanças, pois os crioulos ainda eram 42,9\% em 1818 e os africanos atingem tal patamar, superando-o, em 1829. No cômputo global de todas as faixas etárias agregadas, os africanos só suplantaram os crioulos em 1824, quando eram 50,7\% da escravaria. ${ }^{6}$

Em meio a essa transformação, em 1820, o senhor de Samuel da Rocha morreu sem o libertar em testamento, caminho mais efetivo para conseguir alforria em Porto Feliz. Assim, quando do crescimento da escravidão africana e da ampla predominância da alforria de crioulos, sobretudo em testamento, o crioulo Samuel teve frustradas suas expectativas de liberdade, se é que almejou a alforria testamentária e a liberdade de uma sociedade escravista. ${ }^{7}$ Ainda que nem todas as manumissões fossem registradas, Samuel e sua família não foram privilegiados pelo vigário colado. Antes, uma outra família escrava, com todos os membros alforriados desde 1803, tornou-se a grande beneficiada por André da Rocha Abreu, que também a fez herdeira. Nela, o maior favorecido, Jesuíno José da Rocha, herdou do padre até o título de senhor de engenho. A Samuel e sua parentela se reservaram a permanência em um novo cativeiro ou uma nova condição de dependência. Passaram a ser agregados ou escravos de membros da família privilegiada, em especial, do senhor de engenho pardo Jesuíno José da Rocha e, depois de seu falecimento em 1836, de sua mulher, a parda Dona Feliciana Maria de Jesus. ${ }^{8}$

Com a morte e a mudança de senhor, momentos decisivos na vida dos escravos, quais os destinos e as trajetórias de Samuel e dos seus parentes? O Quadro 1 demonstra que a parentela do carpinteiro era relativamente ampla. Contando seu pai, sua mãe, seus três irmãos, sua esposa, suas três cunhadas, seu padrasto, nove afilhados escravos e nove livres, são 28 pessoas. Excluídos a esposa, virtuais sobrinhos, os afilhados livres, $18 \mathrm{em}$ algum momento 
foram escravos. Experiências de cativos em sua maioria crioulos, quanto tempo viveram na escravidão e na liberdade?

Não é possível saber para todos (cf. Quadro 1), mas o padrasto de Samuel, (1) Fortunato crioulo, em 1815, aos 37 anos de idade, era escravo do padre. Em 1820 e 1824, aos 46 anos, era agregado do herdeiro Jesuíno. Provavelmente ficou forro no ano da morte do padre, em 1820, aos 42 anos de idade. Fortunato da Rocha testemunhou um casamento não mais como escravo em 1825. ${ }^{\circ}$ Em 1829 era um chefe de domicílio, negro e pedreiro, de 49 anos de idade. Estava acompanhado da esposa Joana, mãe de Samuel. ${ }^{10}$ Em 1831, ainda casado, foi padrinho de uma cativa. ${ }^{11}$

Fortunato fora escravo do também padre Domingos da Rocha Abreu, irmão de André, quer dizer, já mudara de senhor antes de ser agregado. Era filho de pais casados e assim a experiência de família escrava, corriqueira em Porto Feliz, não lhe era estranha. Casara-se com a mãe de Samuel em outubro de $1817 .{ }^{12}$ Fortunato viveu escravo por 42 anos, pelo menos quatro como agregado e quatro como chefe de domicílio. Casado por 14 anos, desfrutou de liberdade por ao menos 11 anos.

\begin{tabular}{c|c|c|c|c|c|c|c}
\hline Nome & $\begin{array}{c}\text { Ano de } \\
\text { nascimento }\end{array}$ & $\begin{array}{c}\text { Tempo } \\
\text { estimado } \\
\text { de } \\
\text { escravidáo }\end{array}$ & $\begin{array}{c}\text { Tempo } \\
\text { mínimo } \\
\text { de } \\
\text { liberdade }\end{array}$ & $\begin{array}{c}\text { Tempo } \\
\text { mínimo } \\
\text { de } \\
\text { agregação }\end{array}$ & $\begin{array}{c}\text { Tempo } \\
\text { mínimo de } \\
\text { chefia de de } \\
\text { domićlio }\end{array}$ & $\begin{array}{c}\text { Morte e/ou } \\
\text { última } \\
\text { referência nas } \\
\text { fontes }\end{array}$ & $\begin{array}{c}\text { Grau de } \\
\text { parentesco } \\
\text { como } \\
\text { Samuel }\end{array}$ \\
\hline $\begin{array}{c}\text { Fortunato } \\
\text { Rocha }\end{array}$ & 1780 & 42 & 11 & 4 & 7 & $1831(51)$ & Padrasto \\
\hline $\begin{array}{c}(2) \\
\text { Joana Leite }\end{array}$ & 1788 & 33 & 10 & 4 & - & $1831(43)$ & Mãe \\
\hline $\begin{array}{c}(3) \\
\text { André da } \\
\text { Rocha }\end{array}$ & 1812 & $?$ & $?$ & - & - & 1834 & Irmão \\
\hline $\begin{array}{c}(4) \\
\text { Domingos } \\
\text { da Rocha }\end{array}$ & 1742 & 73 & - & - & - & $1817+(73)$ & Pai \\
\hline $\begin{array}{c}(5) \\
\text { Abraão da } \\
\text { Rocha }\end{array}$ & 1796 & 28 & 12 & - & 8 & $1836+(40)$ & Irmão \\
\hline $\begin{array}{c}(6) \\
\text { Mariana } \\
\text { Angola* }\end{array}$ & 1803 & 24 & - & - & - & $1843+(40)$ & Cunhada \\
\hline $\begin{array}{c}(7) \\
\text { Domingos } \\
\text { da Rocha }\end{array}$ & 1792 & 35 & 7 & - & - & $1835+(42)$ & Irmão \\
\hline
\end{tabular}

(continua) 
Samuel da Rocha: escravo, aparentado, forro...

(continuação)

\begin{tabular}{c|c|c|c|c|c|c|c}
$\begin{array}{c}(8) \\
\text { Teodora } \\
\text { Crioula }\end{array}$ & 1793 & 50 & - & - & - & $1843(50)$ & Cunhada \\
\hline $\begin{array}{c}(9) \\
\text { Samuel } \\
\text { Rocha }\end{array}$ & 1802 & 28 & 34 & - & 34 & $1862+(62)$ & Protagonista \\
\hline $\begin{array}{c}(10) \\
\text { Rosa } \\
\text { Arruda }\end{array}$ & 1800 & - & - & - & - & - & Esposa \\
\hline $\begin{array}{c}(11) \\
\text { José } \\
\text { Crioulo }\end{array}$ & 1841 & 23 & - & - & - & 1864 & Afilhado \\
\hline $\begin{array}{c}(12) \\
\text { Cândida }\end{array}$ & - & 26 & - & - & - & 1860 & Comadre \\
\hline $\begin{array}{c}(13) \\
\text { Vicente }\end{array}$ & 1834 & 26 & - & - & - & 1860 & Afilhado \\
Crioulo & 186 & & - & - & - & & \\
\hline
\end{tabular}

Quadro 1. Escravidão, liberdade, agregação e chefia

de domicílio dos parentes de Samuel.

* tempo de escravidão apenas no Brasil

+ ao lado do ano indica ano da morte

() consta a idade no ano da morte e/ou a última referência documental.

Excluímos certos parentes do trabalho, sobretudo afilhados, por questões de espaço.

A mãe de Samuel, (2) Joana, também foi agregada de Jesuíno José da Rocha depois da morte do padre André em 1820. Como seu segundo marido Fortunato, não foi liberta no testamento do vigário e nem encontrada em alforrias cartoriais. Mas o fato de ser agregada no ano da morte do padre atesta que recebeu alforria, provavelmente dada pelo vigário. Em 1829, no domicílio de seu marido, estava ao lado de seu filho André, de 17 anos. Excluindo-se a possibilidade de seu falecido primeiro marido ter $\operatorname{cornos},{ }^{13}$ pela idade André era apenas filho de Joana, então com 42 anos, ${ }^{14}$ tido na época que era casada com Domingos, já que ela só se uniu a Fortunato em 1817. O novo esposo foi registrado como casado em um batismo de 1831, o que indica que Joana ainda era viva. Destarte, ela viveu 33 anos como escrava e pelo menos dez como liberta. Seu filho (3) André da Rocha foi reconhecido como "filho de Domingos da Rocha e de Joana Leite, escravos que foram" do reverendo André da Rocha Abreu, quando se casou em 1834 com 
Antonia Nobre, ambos libertos. ${ }^{15}$ Diferente de Campos dos Goitacazes entre 1750 e 1830 (SOARES, 2005) e semelhante a São José do Rio das Mortes de 1750 a 1850, Minas Gerais (LIBBY, 2009), em Porto Feliz do século XIX filhos de libertos não tendiam a ser caracterizados como escravos em assentos paroquiais, ao menos nenhum caso foi ainda constatado. Logo, sendo liberto André, irmão de Samuel, também nasceu escravo, alforriando-se em momento impreciso.

O pai de Samuel, (4) Domingos da Rocha, que deixou viúva Joana crioula, ainda foi reconhecido como pai no casamento de seu filho André, em 1834, mesmo depois de estar morto há pelo menos 17 anos. Em 1815, ele era escravo do padre André com respeitáveis 73 anos de idade. O casamento de seu filho foi a única ocasião em que o africano mina Domingos, que faleceu escravo, foi registrado com o sobrenome Rocha. Portanto, integrantes da família que ficaram anos ou a vida inteira na escravidão carregaram o nome senhorial até para o além-túmulo, como é o caso de Domingos da Rocha, 17 anos após seu óbito e 14 anos depois do fenecimento de seu senhor. O mesmo se deu com o nosso testador protagonista Samuel. Depois de morto, em um auto de ação de liberdade, de 1864, referiram-se a ele com o sobrenome Rocha, bem como em seu inventário post-mortem de $1862 .{ }^{16}$

Outro irmão de Samuel, (5) Abraão, como escravo de Jesuíno José da Rocha, se consorciou com a cativa Mariana Angola em 1822, ${ }^{17}$ ele com 25 anos de idade. Em 1824 ainda era escravo. Em 1829, ela era da mesma condição e ele não estava no domicílio de seu senhor. Em 1834 apadrinharam a filha de um casal forro, sendo Mariana ainda cativa de Jesuíno e sem se aludir à condição jurídica do padrinho Abraão da Rocha, com sobrenome. Em dezembro do mesmo ano, ele novamente foi padrinho sem destaque de sua condição jurídica. ${ }^{18}$ Faleceu livre como Abraão da Rocha em dezembro de 1836, aos 40 anos de idade, enterrado com os sacramentos necessários no cemitério da Irmandade de São Benedito. ${ }^{19}$ Viveu pelo menos 28 anos na escravidão e 12 na alforria sem ser encontrado como cabeça de domicílio.

A esposa (6) Mariana Angola tinha 16 anos de idade em 1820. Em 16 de outubro de 1837, viúva de Abraão, casou com Caetano 
da Guiné, escravos de Feliciana Maria de Jesus, viúva do senhor Jesuíno. ${ }^{20}$ Portanto, a ex-cunhada de Samuel ainda era escrava em 1837, assim permanecendo em 1843 aos 40 anos de idade. Como cunhada de Samuel ficou 15 anos em escravidão, precisamente entre seus estimados 18 e 33 anos de idade, de 1822 e 1836, com plena capacidade de lhe fornecer sobrinhos.

O terceiro irmão de Samuel da Rocha, (7) Domingos, escravo do padre entre 1792 e 1818 e de Jesuíno entre 1820 a 1828, casou em novembro de 1819 com Teodora Crioula, ambos com cerca de 25 anos de idade. ${ }^{21}$ Domingos da Rocha registrou sua carta de liberdade em 26 de maio de 1830, escrita em 6 de outubro de 1828, na qual o senhor pardo Jesuíno afirmou que era senhor de um "crioulo de nome Domingos, casado, de idade de 30 anos mais ou menos". Disse mais que o escravo lhe fora doado com a condição de que, quando pagasse 120 mil réis, deveria ser-lhe passada carta de liberdade. ${ }^{22}$ Após 26 anos de trabalho escravo para o padre André e de quase 10 anos para o senhor Jesuíno, o forro desfrutou de liberdade em seus últimos 7 anos de vida.

Já era morto em 18 de março de 1835, ocasião em que a escrava (8) Teodora crioula, viúva de Domingos, casou-se com Antonio da Guiné, escravo da viúva de Jesuíno. ${ }^{23}$ Novamente uma ex-cunhada de Samuel ainda era escrava em 1835, continuando nesta condição em 1843, aos 50 anos de idade. Como cunhada de Samuel, ela viveu 15 anos em cativeiro, de 1819 a 1834, entre 25 e 40 anos de idade, com grande capacidade reprodutiva.

Infelizmente, dispomos de registros de batismo de escravos apenas para o período posterior a 1831, e só um era de um escravo de Jesuíno. Para as cunhadas cativas de Samuel, Mariana e Teodora, as décadas de 1820 e 1830 seriam, respectivamente, as de maior fertilidade. Assim, não é improvável que filhos dessas cativas, sobrinhos de Samuel, homem sem filhos, ainda fossem cativos na década de $1840 .{ }^{24}$ Mas não há indícios sobre eles nas fontes.

O protagonista (9) Samuel, como observado, nasceu no limiar dos Oitocentos. Viveu escravo do padre André até a morte de seu senhor. Foi alforriado por volta de 1828 aos 28 anos de idade, pouco mais ou menos como se dizia na época. ${ }^{25}$ Logo, vivenciou seu período formativo e sua maturidade como escravo de outros homens, 
observando parentes na mesma situação ou como agregados. Porém, já era casado em 1831 quando testemunhou um casamento de escravos do capitão-mor, voltando a testemunhar outros casórios entre 1834 e $1846,{ }^{26}$ sempre assinando com cruz por não saber ler e escrever, como disse em testamento. Não testemunhou casamentos de livres, mas, entre 1826 e 1857, foi padrinho de nove rebentos nascidos livres, sete vezes ao lado de sua mulher. Na primeira ocasião que apadrinhou ainda era escravo, mas já identificado com o sobrenome Rocha, ${ }^{27}$ num dos pouquíssimos casos em que um escravo apadrinhou uma criança livre, uma parda filha de pai incógnito. Os compadres livres ou forros de Samuel não tinham nenhum título de distinção.

Nos batismos de escravos, também se fez compadre nove vezes entre 1832 e 1858, seis das quais juntamente com sua mulher. Em apenas uma ocasião tratava-se de batismos de escravos de herdeiros dos seus falecidos senhores. ${ }^{28}$ Assim, nosso personagem forro sem filhos teve 18 afilhados, o que indica que era bem relacionado na comunidade portofelicense e desfrutava de algum prestígio. Em apenas em um dos batismos, em 1841, aludiu-se à sua condição de liberto, quando ele já vivia como tal há cerca de 13 anos e contava 41 anos de idade. Já era chefe de domicílio em 1836 e 1843 e seu inventário foi aberto dois anos depois de seu testamento. ${ }^{29}$ Samuel da Rocha viveu 28 anos de sua vida como escravo e 34 como forro.

Pouco sabemos sobre sua esposa. (10) Rosa Arruda estava com 40 anos de idade em 1843 e era casada com Samuel desde 1831. Mesmo ainda capaz de gerar filhos, não os teve, como ele asseverou em testamento. Sabemos apenas que ela, como parda, tinha antepassado escravo e estava inconformada com a escravidão de seu afilhado, o que a fez mover uma ação de liberdade em 1864, dois anos após a morte de seu marido. Muito mais do que a escravidão em si, incomodava-a o fato de o afilhado ter sido batizado como livre e permanecer escravo. Nessas circunstâncias, argumentou que moveu a ação pelo "dever de madrinha". João, um cativo que herdara de seu marido, permanecia escravo em 1862, no valor de dois contos de réis. João era solteiro, talvez sem parentes. Quem não tem madrinha morre escravo. 
Os forros da família de Samuel expressam bem que, em geral, cativos aparentados, casados, antigos no plantel e crioulos, como André, Domingos e Abraão, irmãos de Samuel, e mesmo o protagonista, tinham mais chances de chegar à alforria; não que isso fosse fácil, mas também não era impossível ou uma realidade distante. Em relação ao grau de parentesco com Samuel, seu pai africano morreu escravo, sua mãe crioula foi escrava pelo menos até a morte do padre André, em 1820, saindo do cativeiro com quase 32 anos de idade, pois estava com 42 primaveras na lista nominativa de 1829. O irmão Domingos viveu escravo entre cerca de 1792 e 1828, mais ou menos 36 anos de cativeiro, e desfrutou de sete anos de alforria. O irmão Abraão foi escravo aproximadamente até 28 anos de idade. Todos ou quase todos mudaram de senhor ou se tornaram agregados da família herdeira beneficiada pelo padre. $\mathrm{O}$ motivo da postura diferenciada do padre André deve estar ligada à atitude dos escravos. Como muito bem salientou Mirian Hartung (2005), os cativos mais aparentados tendiam a ser privilegiadas por seus senhores no recebimento de heranças e legados. Os pais de Samuel tiveram quatro filhos, ao passo que a família eleita teve sete.

A propósito, Samuel e seus irmãos Abraão, André e Domingos também não foram encontrados como pais em uma amostragem de 3816 registros de batismo de livres para os anos de 1820 a 1845, e de 1564 batismos de escravos para o período de 1831 a $1845 .{ }^{30}$ Se as mulheres cativas tendiam a prolongar a idade da última concepção (FLORENTINO; GÓES, 1997 p. 133-139), chama atenção, mas ainda não há resposta, o fato de que a segunda geração biológica masculina da família que não foi privilegiada (Samuel e seus irmãos) não tenha produzido descendência. Sabemos que eles não migraram e Samuel foi categórico ao afirmar em testamento que não teve filhos. Não há certeza se casou quando ele e/ou sua esposa eram escravos, mas pelo menos dois de seus irmãos, Abraão e Domingos, se uniram matrimonialmente a escravas. Restringindo a análise ao último ano para o qual há certeza de que ao menos um dos irmãos de Samuel era vivo, também nenhum deles foi encontrado como pai em 764 registros de batismo de escravos para os anos situados entre 1831 e $1836 .{ }^{31}$ Logo, Samuel, sem filhos, também não vira descendentes de seus irmãos no cativeiro. Como sublinhamos, 
porém, faltam dados para os anos anteriores a 1831, quando as cunhadas cativas de Samuel gozavam de capacidade reprodutiva.

Desses aspectos deduz-se que nem sempre a ausência de registros de batismos de filhos indique emigração, pois Samuel e dois de seus três seus irmãos morreram em Porto Feliz. Provavelmente, estar aparentado, mesmo sem filhos, ainda que também com a escravidão, indique enraizamento na localidade, o que influiu na opção pela permanência na vila, e mesmo que migrar - liberdade de movimento, isto é, atributo de livre - fosse afirmação de liberdade e busca de autonomia (CASTRO, 1995; FARIA, 1998).

Se há dúvidas sobre a escravidão dos sobrinhos de Samuel, por outro lado, como demonstra o Quadro 1, certamente Samuel viu seu pai morrer escravo, sua mãe, seus irmãos e cunhadas passarem a maior parte da vida em cativeiro, sem contar seus nove afilhados escravos, isto é, seus filhos espirituais. Como notamos, bastou Samuel morrer em 1864 para que sua esposa movesse uma ação de liberdade contra João Leite de Camargo, cunhado do senhor Jesuíno, portanto, membro da família privilegiada pelo padre André. O objetivo da ação era alforriar seu afilhado (11) José crioulo, nascido em 1841, cujo padrinho era seu falecido marido Samuel. ${ }^{32}$ Assim, também José, afilhado de Samuel, ambientava-se como escravo há pelo menos 23 anos.

Contudo, Samuel, em vida, não deve ter permitido que sua esposa entrasse com a ação contra a parentela senhorial, pois crescera junto com a ex-família cativa eleita pelo padre. Distintos social e juridicamente ao longo de suas vidas, eram todos oriundos dos centenários e proeminentes Rocha. Isso talvez ajude a compreender que, mesmo com toda a escravidão da família, Samuel não deixou de levar consigo o nome senhorial, identificando-se com ele e reatualizando-o às vésperas da morte, quando ditou testamento doente, mas em seu perfeito juízo. Não sabemos se os pais ou o senhor de Samuel escolheram seu bíblico nome de batismo, mas numa sociedade onde o sobrenome era construído ao longo da vida, aludi-lo em testamento é significativo da deferência que o forro prestava ao padre e à memória senhorial. Nem mesmo seus pais foram referidos com sobrenome no testamento. Sua mãe chegou à liberdade e carregava um sobrenome, Joana Leite, quando do 
casamento do seu irmão André em 1834. Seu pai, o africano mina Domingos, embora escravo, também tinha sobrenome nesse casório, Domingos Rocha, ainda que estivesse defunto. ${ }^{33}$ Quiçá o irmão André da Rocha salientou o nome completo do pai, único membro da família a morrer escravo, como recurso simbólico de afirmação de liberdade. Se a escravidão desonrava (PATTERSON, 1982), a liberdade, ainda que post-mortem, era significativa.

Contudo, Samuel não afirmou os sobrenomes dos pais no testamento, ao contrário do modo como se referiu aos testamenteiros. Livre, Samuel era um Rocha, usando o nome que diferencia pessoas e famílias nas sociedades em que vivem (GINZBURG, 1991), tal como o sobrenome senhorial no passado escravista brasileiro. Sobrenome, aliás, tendia a se uma das maiores diferenças entre egressos do cativeiro e escravos (GUEDES, 2008; HAMEISTER, 2006; SOARES, 2002). Com certeza, era preferível carregar um sobrenome senhorial do que uma marca do passado escravo. Mesmo ditando o nome dos pais, como rezava a legislação sobre testamentos, não afirmou que foram escravos, ainda que não precisasse fazê-lo em um lugarejo onde todo mundo conhecia todo mundo. Complementarmente, comum em Porto Feliz do século XIX, mas diferente de outras searas (FARIA, 2005; OLIVEIRA, M., 1979), forros geralmente não se reportavam à sua pretérita condição escrava em testamento e tampouco ao nome de seus senhores. Sem esquecer a ascendência familiar, mas retirando dela o passado escravo, em 1860, aos 60 anos de idade, com 32 de liberto, casado com uma livre desde 1826, com os senhores André e Jesuíno falecidos, respectivamente, há 40 e 25 anos, não valia muito a pena reiterar a memória familiar da escravidão que se apagava em sua condição senhorial. Ao morrer senhor de escravo e aparentado com a liberdade, destacou em suas lembranças as irmandades, a igreja e "minha ferramenta de carpinteiro".

\section{Carpinteiro}

Reiterar à consciência a ferramenta de carpinteiro indica sua utilidade em um mundo eminentemente agrário voltado em grande 
parte à produção de açúcar calcada, majoritariamente, sobre o trabalho escravo, mas também onde trabalhadores especializados, inclusive assalariados, estavam no cerne do processo produtivo (SCHWARTZ, 1988, p. 261-269). A propósito, em agosto de 1822, o capitão-mor de Porto Feliz solicitou aos governadores interinos da capitania que um pardo egresso do cativeiro não fosse recrutado para o serviço militar. Em sua petição, afirmou que os governadores tinham a "agricultura como a mãe da sociedade e base do poder", o que o levava a pedir, "em abono das fábricas de açúcar", a demissão do serviço militar o soldado Antonio Pedroso de Campos. Argumentou que o soldado era "um hábil carpinteiro, e o melhor maquinista de engenhos de açúcares, os quais sendo por estas paragens construídos só de madeira amiúde se quebram". Para enfatizar ainda mais sua súplica, o capitão prometeu que daria "um recruta branco, e moço, em [lugar] do soldado por quem imploro, que é pardo, e idoso". ${ }^{34}$ Dessa maneira, segundo o capitão, o trabalho de um habilidoso carpinteiro tornava sua presença de importância central no processo de produção de açúcar, já que a falta daquele maquinista de engenhos ocasionaria ruína de agricultores e credores e prejuízos para os dízimos.

Samuel não seria o melhor maquinista de engenhos, mas fora escravo de um senhor de engenho, demonstrando a possibilidade de ter sido um carpinteiro muito útil ao padre André. Da perspectiva senhorial do capitão-mor, a exploração do trabalho de um pardo especializado em carpintaria apenas colaborava para o bom funcionamento dos engenhos. Mas também reconhecia que a habilidade do trabalhador tornava os senhores dele dependentes. Assim, se o senhor o explorava, por outro lado, o trabalho dava margens de negociação ao trabalhador, autonomia. Por seus ofícios, trabalhadores especializados eram estimados e respeitados socialmente, ${ }^{35}$ a ponto de se inverterem hierarquias sociais de uma sociedade escravista: trocar um branco moço por um pardo idoso. Ou será que as palavras do capitão remetem mais à exploração do trabalho alheio, ao invés de valorar os trabalhadores pelo que faziam? Uma hipótese não exclui necessariamente a outra, mas cremos que prevaleça a segunda, ao menos na perspectiva dos trabalhadores. 
O negro forro Samuel conseguiu certos ganhos de sua ocupação até certo ponto especializada. ${ }^{36}$ Soldado da Guarda Nacional em 1836, depois de liberto há uns 12 anos, já morava no nicho "urbano" do município, onde a carpintaria também rendia bons frutos para um egresso do cativeiro. Nesse ano, as listas nominativas dividem os 614 domicílios da vila em 15 quarteirões, cinco dos quais considerados como "nicho urbano" porque traziam nomes das ruas de Sorocaba, do Porto, da Ponte, da Palha e do Bairro Alto. Ainda que houvesse outras ruas, e de fato havia, os demais quarteirões abarcavam bairros rurais, majoritariamente, desnecessário dizer, de "ocupações agrárias". Nos urbanos, os ofícios dos chefes de domicílios, associados às suas cores, se distribuíam da seguinte forma: 2 padres brancos, 1 escrivão da Igreja branco que também ensinava primeiras letras a meninos, 1 solicitador de causas branco, 9 alfaiates ( 6 pardos, 1 preto e 2 brancos), 1 pardo alfaiate "também guia do caminho do Cuiabá", 1 pardo arreador do caminho de Santos, 1 pardo camarada de viagem, 15 carpinteiros (6 pardos, 2 pretos e 7 brancos), dentre os quais o preto Samuel da Rocha, morador na Rua do Porto do quarteirão 1, 3 ferreiros (2 brancos e 1 pardo), 1 latoeiro branco, 1 lombilheiro branco, 1 seleiro pardo, 3 sapateiros (2 pardos e 1 branco), 1 telheiro branco, 1 ourives branco, 1 cirurgião branco, 1 branco pescador, 1 branco escrivão da igreja, 1 branco que vivia do jornal de seus escravos sapateiros, 1 pardo que comprava e vendia fumo, 1 pardo que vivia de suas violas, 1 tropeiro branco, 5 costureiras ( 3 brancas e 2 pardas), 20 fiandeiras (7 brancas, 2 negras e 11 pardas), 2 tecelões brancos, 2 louceiras negras, 24 cozinheiras (14 brancas e 10 pardas), 33 jornaleiros (18 pardos, 10 brancos, 1 negro e 4 pretos), 12 negociantes brancos, 1 quitandeira branca, 7 taberneiros (6 brancos e 1 pardo), 19 que viviam de suas agências ou de seu negócio (8 brancos, 7 pardos, 3 pretos e 1 china), 17 lavradores, dos quais 12 brancos e 5 pardos, seguindo a tendência de os brancos estarem mais representados nas lides agrárias (GUEDES, 2009), e 2 que viviam de suas hortaliças (1 pardo e 1 branco).

Conquanto houvesse uma representação de cor de acordo com ofício ou ocupação desempenhados, ou uma tendência de determinadas atividades serem exercidas por pessoas de determinada 
cor, não vigia qualquer exclusividade (GUEDES, 2009), o que significa que apenas o trabalho não é critério muito seguro para diferenciar negros, pardos e brancos. Com dizia o viajante francês Saint-Hilaire, que passou por Porto Feliz por volta de 1820, referindo-se aos senhores de engenho da vila, "devia haver um bom número de mestiços que passavam por brancos" (SAINTHILAIRE, 1976, p. 182). Gente de todas as cores via nas atividades artesanais e nos serviços do nicho urbano uma oportunidade de acumulação, pois nele quase não havia "atividades rurais". Em 1836, eram 208 domićlios no nicho urbano de Porto Feliz. Ainda que o censo desse ano esteja incompleto, reduzindo a área rural, informa-se o rendimento de 291 domicílios. Entre os 208 urbanos, 169 eram desprovidos de escravos, como o de Samuel carpinteiro. Para 52 desses trabalhadores, listou-se algum ganho diário ou anual. Por exemplo, o inspetor de quarteirão, solicitador de causas, branco, viúvo, de 42 anos de idade, Joaquim do Vale Pereira, declarou rendimento anual de 100 mil réis, enquanto o jornaleiro pardo solteiro de 33 anos Salvador Gervásio disse que ganhou 320 réis por dia, o que daria quase 117 mil réis se trabalhasse todos os dias do ano. Outro jornaleiro pardo de 60 anos teve de saldo 48 mil réis anuais. Mais jovem que todos eles, 32 anos de idade segundo as listas, o carpinteiro preto Samuel ganhou 150 mil réis anuais. Entre os oito oficiais carpinteiros sem cativos superou todos em rendimento da atividade. ${ }^{37}$

Evidentemente, uma medida um pouco mais aproximada deveria levar em conta o número de filhos e suas idades, a presença de agregados, o ciclo vital, etc. Mas Samuel, forro há 8 anos, era sem filhos e sem agregados em 1836, o que, se levava à falta de cooperação no trabalho, por outro lado não gerava o ônus no sustento de filhos menores. Similarmente a mulheres forras de São João Del Rey do século XVIII, a ausência de filhos podia contribuir para a acumulação (FARIA, 2005).

Para 1843, segundo e último ano em que encontramos Samuel da Rocha como chefe de domicílio, infelizmente não há dados sobre rendimentos. Sabemos apenas que era forro há 15 anos, continuava carpinteiro sem escravo, casado, 42 anos de idade, negro, morador em dos quarteirões da vila, mas agora com dois agregados, 
Antonio, de 22 anos, e José, de 20, ambos pardos solteiros. Sua mulher parda contava "40 anos [sic]". Sendo assim, aparentemente pelo menos, dispunha de parceiros no trabalho de carpintaria, ocupação quase exclusivamente masculina. Se contou com alguém foi com esses dois agregados, pois não era incomum agregados trabalharem com chefes de domicílios (MACHADO, 2008). Talvez fossem aprendizes sob tutela durante o aprendizado.

Ainda no campo das possibilidades, Samuel já desempenhava seu ofício de carpinteiro quando era escravo do padre André, já que os especializados carpinteiros eram muito úteis no trabalho dos engenhos. Destarte, essa experiência de trabalho escravo foi levada e aproveitada na vida de forro na vila. Não há certeza para o caso de Samuel, mas seu irmão Domingos, por exemplo, pagou, ao menos parcialmente, por sua carta de alforria em 1828, o valor de 120 mil réis. Nessa época era possível comprar mais da metade de um escravo de 25 anos avaliado em 280 mil réis no inventário de Antonio Caetano, por exemplo. ${ }^{38}$ Não se pode, assim, descartar a ideia de que Samuel tenha pago por sua liberdade com o suor de seu trabalho de carpinteiro escravo, e mesmo que a maior parte das alforrias em Porto Feliz fossem gratuitas (GUEDES, 2008, cap. 4). Para um senhor de engenho desfazer-se de um valioso trabalhador podia ser oneroso. Se foi o caso de Samuel pagar por sua alforria, a experiência de carpintaria do escravo foi decisiva.

Certo mesmo é que, na ocasião do testamento em 1860 já não era escravo há muito tempo, aproximadamente 40 anos. Então, servia-se do braço escravo para o ajudar no processo de trabalho. Seu escravo João foi avaliado como carpinteiro em 1862, no valor de 2 contos de réis. Era o seu bem mais valoroso, e Samuel sugere no testamento que não queria levar para o além-túmulo a dívida para com sua comadre escrava, uma parenta espiritual. (12) Cândida era sua comadre desde fevereiro de 1834, momento em que ele e sua esposa foram padrinhos do escravo (13) Vicente, filho de pai incógnito, ${ }^{39}$ ou seja, sua comadre e talvez seu afilhado vivessem como propriedade de outros homens há pelo menos 26 anos. Devia saber que ela talvez precisasse dos 400 mil réis para ajudar na compra de sua liberdade ou na de seu filho, ou para qualquer outro fim. Os 400 mil réis em 1860 equivaleriam a 1/5 
do valor do escravo carpinteiro João, ou mais da metade do valor da casa em que Samuel morava, de 700 mil réis. Daí o condicionamento da liberdade de João ao pagamento da dívida.

Frequentemente, os testamentos eram redigidos quando os testadores estavam enfermos, ou seja, os testadores não demoravam muito para fenecer depois do momento da redação. Samuel da Rocha não foi uma exceção. Momento de expiar as culpas, de se redimir do pecado do cativeiro (DAVIS, 2000; SOARES, 2009), libertou condicionalmente seu escravo. É bem provável que com peso na consciência deixou-lhe até a ferramenta de carpinteiro. Eis um movimento aparentemente paradoxal: a experiência de trabalho escravo do carpinteiro Samuel pode ter servido para comprar sua alforria, mas uma vez senhor carpinteiro a exploração post-mortem de seu escravo parceiro de oficio visou libertá-lo. Mas pesava na consciência pagar à comadre escrava. Entre o pagamento à sua parenta espiritual de longa data e a liberdade incondicional de seu jovem escravo a balança da consciência pendeu mais para o parentesco. Como ele próprio e sua família viveram anos na escravidão, parece que isso não incomodava, nem deveria, pois também viu quase todos chegarem à liberdade. Quiçá se daria o mesmo com seu escravo.

Porém, antes da possibilidade de liberdade do escravo João, o carpinteiro forro Samuel bem desfrutou dos serviços cativos de carpintaria. Não há certeza quando o novo senhor Rocha adquiriu o escravo, certamente com a ajuda de sua mulher. $\mathrm{O}$ carpinteiro negro era chefe de domicílio em 1836 e 1843, quando ainda não era senhor. No inventário de 1862, o cativo João, carpinteiro, foi arrolado com 24 anos de idade. Estava só no plantel. Se não era crioulo, Samuel burlou a lei de 1831 que proibia a entrada de africanos como escravos no Brasil (MAMIGONIAN, 2005). Seu escravo podia ser um crioulo vindo do sul ou do nordeste do país pelo tráfico interno. Samuel não deve tê-lo recebido como dote de casamento de sua esposa parda porque a prática de dotar com escravos, comum a famílias de elite, o que não era sequer o caso de sua mulher, estava cada vez mais em desuso em São Paulo no século XIX (NAZZARI, 2001). Por conseguinte, deve ter trabalhado muito como carpinteiro para comprar o escravo, ou seja, 
reproduziu a escravidão com o próprio suor de seu trabalho. Seu trabalho livre especializado ajudou a explorar o trabalho escravo alheio, também especializado. A exploração escravista se sobrepôs à ocupação comum e a uma suposta identidade com a vida (passada) em cativeiro. Samuel era um Rocha, sobrenome de senhor de escravo.

\section{O escravo de Samuel é outra história}

Da trajetória de Samuel, podem-se observar alguns aspectos não tão incomuns a forros. Nasceu em cativeiro e permaneceu escravo até mais ou menos seus 28 anos de idade. Participava das instâncias de socialização de libertos, como as irmandades de negros e pardos de Nossa Senhora da Boa Morte e de São Benedito. Apadrinhou nove crianças livres e nove escravas. Se o "empenho" e "o compadresco" eram, no tempo do rei, mas também no império do Brasil, "uma mola real de todo o movimento social" (ALMEIDA, 1985, p. 126), ser forro e senhor não significou vedar relações com escravos e outros egressos do cativeiro, nem com livres. Seria um antagonismo em equilíbrio, diria Gilberto Freyre (1987).

Logo, o carpinteiro negro Samuel da Rocha era chefe de domicílio em 1836 e 1843, quando ainda não tinha escravo. Reproduziu a escravidão com o próprio trabalho e nem por isso deixou de ser carpinteiro. Para seu cativo deu a ferramenta de carpintaria para se libertar. Sabia que o trabalho artesão propiciava meios de inserção social para ex-escravos, inclusive para o pagamento da liberdade. Pelo exposto, a experiência de trabalho em cativeiro trazida para a vida em liberdade contribuía para a aquisição de escravos e gozo de estima. Aliás, dos ex-escravos homens do padre André da Rocha Abreu de que se tem informação, quase todos que encabeçaram domicílios tinham um ofício, como o padrasto de Samuel, Fortunato da Rocha, pedreiro, e Francisco da Rocha, sapateiro, sendo que este último era também senhor de escravo. ${ }^{40}$ Em suma, esses casos estão longe daquelas imagens nas quais um forro compra escravo e para de trabalhar. Ser senhor não 
é sinônimo de ociosidade, e trabalho escravo e trabalho livre não "eram sistemas historicamente incompatíveis" (EISENBERG, 1989, p. 237, 223).

No inventário de Samuel havia bens relativamente significativos para quem passou mais de um terço da vida na escravidão. Em 1860, valiam 2 contos e 832 mil réis, incluindo João carpinteiro, no valor de dois contos, uma morada de casas, 700 mil réis, dois terrenos avaliados em 28 mil réis, etc. Devia a dez pessoas a quantia de 114.020 réis, incluindo um escravo de Francisco de Arruda, que sequer foi nomeado, mas ainda assim demonstra certa capacidade de crédito dos escravos, tal como a comadre Cândida. As dívidas demonstram também a consideração social que o forro desfrutava, pois dívidas, além do aspecto econômico, significam acesso a crédito, co-fiança, confiança. Outrossim, o escravo João foi avaliado no inventário, sugerindo que a dívida ainda não tinha sido paga, embora sua comadre Cândida não tenha sido mencionada entre os credores.

Samuel da Rocha, trabalhador forro carpinteiro, possuía três catres, um armário, duas mesas, uma caixa grande, uma pequena, uma cadeira de palha, dez tábuas, tudo valendo 26 mil réis. A "minha ferramenta de carpinteiro" destacada no testamento valia parcos dois mil réis, o bem de menor valor monetário do inventário, mas muito provavelmente foi o que deu a liberdade a Samuel e talvez desse a seu escravo João. Teria João carpinteiro chegado à alforria no contexto pós-1850, momento a partir do qual o fím do tráfico atlântico de cativos ocasionou a elevação do preço dos escravos? Essa é outra história.

\section{Samuel da Rocha: slave, kindred, freed people, carpenter and master (Porto Feliz, São Paulo, $19^{\text {th }}$ century)}

Abstract: Covering the city of Porto Feliz in the $19^{\text {th }}$ Century, this work analyzes fragments of life trajectory of crioulo carpenter called Samuel da Rocha, who spent more than 25 years in captivity. He changed his master, obtained his manumission and kept one slave, who was also given freedom. Without children, he was also son, brother, compadre, godfather, husband, that's to say, he was involved in a complex network parental, crucial for his social inclusion. Therefore, this article shows that not always cleavage between slavery and freedom takes into account 
social experiences of individuals and groups. Thus, by analyzing a life trajectory it's possible to understand the fluidity of individuals' social identities, as well as to help to understand the aparatus for the exploitation of slave labor, in which Samuel da Rocha was present in both sides.

Keywords: Slavery. Freedom. Carpenter.

\section{Notas}

${ }^{1}$ Museu Republicano Convenção de Itu (MRCI). Pasta 343. Nas citações de documentos antigos a grafia foi atualizada segundo a norma vigente.

${ }^{2}$ Oeste paulista compreende as vilas criadas até 1850, a saber: Itu, Jundiaí, MogiGuaçu, Campinas, Capivari, Piracicaba, Franca, Tietê, Batatais, Rio Claro, Limeira (MARCÍliO, 2000, p. 140).

${ }^{3}$ Por exemplo, "negros e pardos constituíam um corpo político e social que expressava valores e reivindicações que certamente podiam desagradar e preocupar muitos senhores e autoridades coloniais. Não é à toa que Carlos Drummond de Andrade, ao comentar a história das irmandades negras mineiras, afirma que elas serviram de abrigo para a 'luta de classes de pretos contra brancos'. Sua alma de poeta o leva a interpretar cristalinamente a conquista da capela do Alto da Cruz, em Vila Rica, pelos pretos do Rosário como parte da 'luta de classes - luta civil, urbana, longe dos quilombos'” (LARA, 2007, p. 210). Sobre irmandades não segmentadas, cf. OLIVEIRA, A. (1995).

${ }^{4}$ Arquivo de Estado de São Paulo (AESP), Listas Nominativas de Porto Feliz (LNPF), Ano de 1803, $2^{\text {a }}$ Companhia, fogo 235. As demais referências do padre André nas listas mencionadas, utilizadas para aferir informações sobre escravos,

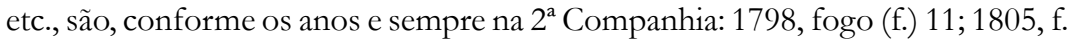
226; 1808, f. 261; 1810, f. 272; 1813, f. 337; 1815, f. 338; 1818, f. 191. Os cálculos das idades, o tempo de vida em cativeiro e em liberdade são aproximações, posto que elaborados com base nas imprecisas informações etárias das listas nominativas, cruzadas a registros paroquiais, testamentos, inventários post mortem, etc. Nas informações etárias oriundas das listas nominativas as idades nem sempre seguem a sequencia dos anos. Assim, as pessoas podem envelhecer alguns anos antes do previsto ou retardar o envelhecimento; em certos casos pode-se até rejuvenescer. Neste artigo, as idades mencionadas são apenas aproximações, mas sem deixarem de ser informações importantes.

${ }^{5}$ Arquivo da Cúria Diocesana de Sorocaba (ACDS), Livro 2 de Casamento de Escravos, fl. 22, 30 e 74v.

${ }^{6}$ Cálculo feito com base nas listas nominativas (AESP, LNPF, 1798-1843).

Anos 90, Porto Alegre, v. 17, n. 31, p. 57-81, jul. 2010 


\section{Roberto Guedes}

${ }^{7}$ Nem sempre os cativos almejavam a alforria (cf. PINHEIRO, 1998).

${ }^{8}$ Em outro trabalho (GUEDES, 2008), nos ocupamos de famílias privilegiadas. Após críticas ao enfoque sobre os que se deram bem, as quais agradecemos, espera-se, neste trabalho inicial, dar conta dos que se deram mal, se for esse o caso. As referências para Jesuíno José da Rocha nas listas nominativas, usadas para aferir várias infor-

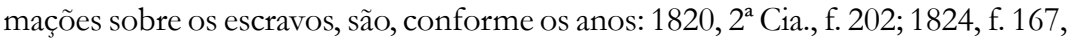
Bairro Quilombo; 1829, 2a Cia., f. 187. Do mesmo modo, as referências da viúva de Jesuíno, Feliciana Maria de Jesus: 1836, Quarteirão 10, Bairro de Santo Antônio, f. 24; 1843, 2 ${ }^{\circ}$ Quarteirão da Vila, f. 114.

${ }^{9}$ ACDS, Livro 3 (1821-1858), Casamento de Escravos, fl. 46.

${ }^{10}$ AESP, LNPF, Ano 1829, 2a Cia., f. 56.

${ }^{11}$ ACDS, Livro 1 (1831-1864), Batismo de Escravos, fl. 4v.

${ }^{12}$ ACDS, Livro 2 (1787-1821), Casamento de Escravos, fl. 74 v.

${ }^{13}$ Dentre os significados de cornos, um figurativo refere aos que "se aparecem nos homens sinais de desonra, que suas mulheres lhes fazem" (MORAES SILVA, 1813, p. 472-473).

${ }^{14}$ AESP, LNPF, Ano 1829, 2a Cia., f. 56.

${ }^{15}$ ACDS, Casamento de Livres, Livro 4 (1818-1837), fl. 123.

${ }^{16}$ MRCI, Inventário de Samuel da Rocha, Pasta 293, Doc. 6; Ação de Liberdade, Pasta 12, Doc. 1.

${ }^{17}$ ACDS, Casamento de Escravos, Livro 3 (1821-1858), fl. 11v.

${ }^{18}$ ACDS, Batismo de Livres, Livro 5 (1834-1846), fl. 6 e 10.

${ }^{19}$ ACDS, Livro de Óbito de Brancos e Libertos (1834-1866), fl. 12v.

${ }^{20}$ ACDS, Casamento de Escravos, Livro 3 (1821-1858), fl. 78v.

${ }^{21}$ ACDS, Casamento de Escravos, Livro 2 (1787-1818), fl. 85v. Apesar de o padre André ainda viver na ocasião do casamento, aludiu-se aos pais do noivo como escravos que foram de André da Rocha Abreu, e aos noivos como de presente escravos de Jesuíno José da Rocha.

${ }^{22}$ MRCI, Livro de Notas, Pasta 176, Livro 12, fl. 43.

${ }^{23}$ ACDS, Casamento de Escravos, Livro 3 (1821-1858), fl. 71v.

${ }^{24}$ As listas nominativas quase sempre não informam a filiação escrava.

251815 é o último ano em que aparece como escravo do padre André. Não consta como cativo de Jesuíno nas listas nominativas, mas foi registrado como padrinho escravo em um registro de batismo em 1826. ACDS, Livro 2 (1818-1829), Batismos de Livres, fl. 33.

${ }^{26}$ ACDS, Casamento de Escravos, Livro 3 (1821-1858), fl. 57, 70, 93

${ }^{27}$ ACDS, Batismos de Livres, Livro 2 (1818-1829), fl. 33; Livro 5 (1834-1846), fl. 53v, 116v, 125v, 193; Livro 6 (1846-1860), fl. 32v, 60v, 87, 154v.

${ }^{28}$ ACDS, Batismos de Escravos, Livro 1 (1831-1864), fl. 13v, 14, 19v, 24v, 74, 156v, $164,166,237$. 
${ }^{29}$ LNPF, Ano 1836, Q. 1, f. 19; 1843, Q. 2 da Vila, f. 147. MRCI, Pasta 293, Doc. 6.

${ }^{30} 1845$ foi considerado o ano-limite, aproximado, para a fecundidade da mulher e cunhadas de Samuel, mesmo depois que as últimas estivessem casadas com outros homens.

311836 é o último ano que uma das cunhadas de Samuel ainda deveria ser casada com um de seus irmãos.

${ }^{32}$ MRCI, Ação de Liberdade, Pasta 12, Doc. 1.

${ }^{33}$ Os sobrenomes aparecem no casamento ACDS, Casamento de Livres, Livro 4 (1818-1837), fl. 123.

${ }^{34}$ AESP, Ordenanças de Porto Feliz, Cx. 54, Pasta 2, Doc. 58.

${ }^{35}$ No extremo sul da Lousiania, EUA, a ascensão da economia açucareira na primeira metade do século XIX permitiu a certos "escravos ganhar habilidades e as prerrogativas que costumeiramente as acompanhavam" (BERLIN, 2006, p. 218). No Brasil, também (cf. ENGEMANN, 2005; SLENES, 1997). Para forros e demais egressos do cativeiro não era diferente.

${ }^{36}$ Até certo ponto porque uma rígida divisão do trabalho não é traço de uma economia pré-industrial (POLANYI, 2000).

${ }^{37}$ LNPF, Ano 1836: Quarteirão 5, Rua da Ponte, f. 1; Quarteirão 15, Rua do Bairro Alto, f. 17; Quarteirão 5, Rua da Ponte, f. 38; Quarteirão 1, Rua do Porto, f. 19. Para os demais carpinteiros, Quarteirão 4, Rua de Sorocaba, f. 13, 17, 33 e 42; Quarteirão 5, Rua da Ponte, f. 11 e19; Quarteirão 2, Rua da Palha, f. 22.

${ }^{38}$ MRCI, Inventário post mortem de Antonio Caetano, Pasta 241, Doc. 5.

${ }^{39}$ ACDS, Batismo de Escravos, Livro 1 (1831-1864), fl. 24v.

${ }^{40}$ LNPF, Fortunato Rocha, Ano de 1829, $2^{\text {a }}$ Cia., f. 56; Francisco da Rocha, Ano de 1829, $2^{a}$ Cia., f. 46.

\section{Referências}

ALMEIDA, M. A. de. Memória de um sargento de milicias. São Paulo: Ática, 1985.

BERLIN, I. Gerações de cativeiro: uma história da escravidão nos Estados Unidos. Rio de Janeiro: Record, 2006.

CASTRO, H. M. M. de. Das cores do silêncio: os significados da liberdade no Sudeste escravista. Rio de Janeiro: Arquivo Nacional, 1995.

DAVIS, D. B. O problema da escravidão na cultura ocidental. Rio de Janeiro: Civilização Brasileira, 2000.

EISENBERG, P. Homens esquecidos: escravos e trabalhadores livres no Brasil-séculos XVIII e XIX. Campinas: Editora da Unicamp, 1989. 


\section{Roberto Guedes}

ENGEMANN, C. Da comunidade escrava e suas possibilidades. In: FLORENTINO, M. Tráfico, cativeiro e liberdade: Rio de Janeiro: séculos XVII-XIX. Rio de Janeiro: Civilização Brasileira, 2005. p. 169-206.

FARIA, S. de C. A colônia em movimento: fortuna e família no cotidiano colonial. Rio de Janeiro: Nova Fronteira, 1998.

- Sinhás pretas, damas mercadoras: as pretas minas nas cidades do Rio de Janeiro e de São João Del Rey (1750-1850). Tese (Concurso de Professor Titular de História do Brasil) - Universidade Federal Fluminense, Niterói, 2005.

FLORENTINO, M.; GÓES, J. R. A paz das senzalas: famílias escravas e tráfico atlântico. Rio de Janeiro, 1790-1850. Rio de Janeiro: Civilização Brasileira, 1997.

FREYRE, G. Casa-grande e senzala: formação da família brasileira sob o regime da economia patriarcal. 25. ed. Rio de Janeiro: José Olympio, 1987.

GINZBURG, C. A micro-história e outros ensaios. Lisboa: Difel, 1991.

GODOY, S. A. de. Itu e Araritaguaba na Rota das Monções (1718-1838). Dissertação (Mestrado em História Econômica) - Instituto de Economia, Universidade Estadual de Campinas, Campinas, 2002.

GÓES, J. R. P. Padrões de alforria no Rio de Janeiro, 1840-1871. In: FRAGOSO, J. et al. (Org.). Nas rotas do império: eixos mercantis, tráfico de escravos e relações sociais no mundo português. Vitória: Edufes, 2006. p. 517-568.

GRAHAM, S. L. Caetana diz não: histórias de mulheres da sociedade escravista brasileira. São Paulo: Companhia das Letras, 2005.

GUEDES, R. Egressos do cativeiro: trabalho, família, aliança e mobilidade social (Porto Feliz, São Paulo, c. 1798-c. 1850). Rio de Janeiro: Mauad; Faperj, 2008.

Ocupação e mobilidade social (Porto Feliz, século XIX). In: BOTELHO,

T. R.; VAN LEEUWEN, M. H. D. (Org.). Mobilidade social em sociedades coloniais e póscoloniais: Brasil e Paraguai, séculos XVIII e XIX. Belo Horizonte: Veredas \& Cenários, 2009. v. 1, p. 137-182.

GUEDES, R.; GODOY, S. Do império português ao império de Brasil: notas sobre legitimidade social de famílias de elite (Itu e Porto Feliz, São Paulo, séculos XVII-XIX). Revista Eletrônica de História do Brasil, v. 10, p. 1-31, 2008.

HAMEISTER, M. D. Para dar calor à nova povoação: estudo sobre estratégias sociais e familiares a partir dos registros batismais da vila do Rio Grande (1738-1763). Tese (Doutorado em História Social) - Centro de Filosofia e Ciências Humanas, Universidade Federal do Rio de Janeiro, Rio de Janeiro, 2006.

HARTUNG, M. Muito além do céu: escravidão e estratégias de liberdade no Paraná do século XIX. Topoi: Revista de História, Rio de Janeiro, v. 6, n. 10, p. 160-182, 2005.

LARA, S. H. Fragmentos setecentistas: escravidão, cultura e poder na América portuguesa. São Paulo: Companhia das Letras, 2007.

Anos 90, Porto Alegre, v. 17, n. 31, p. 57-81, jul. 2010 
LIBBY, D. C. À procura de alforrias e libertos na freguesia de São José do Rio das Mortes (c. 1750 - c. 1850). In: BOTELHO, T. R.; VAN LEEUWEN, M. H. D. (Org.). Mobilidade social em sociedades coloniais e pós-coloniais: Brasil e Paraguai, séculos XVIII e XIX. Belo Horizonte: Veredas \& Cenários, 2009. v. 1, p. 13-46.

LIBBY, D.; FURTADO, J. (Org.). Trabalho livre, trabalho escravo: Brasil e Europa, séculos XVII e XIX. São Paulo: Annablume, 2006.

MACHADO, C. A trama das vontades: negros, pardos e brancos na construção da hierarquia social do Brasil escravista. Rio de Janeiro: Apicuri, 2008.

MAMIGONIAN, B. Revisitando a "transição para o trabalho livre": a experiência dos africanos livres. In: FLORENTINO, M. Tráfico, cativeiro e liberdade: Rio de Janeiro: séculos XVII-XIX. Rio de Janeiro: Civilização Brasileira, 2005. p. 389-417.

MARCÍLIO, M. L. Crescimento demográfico e evolução agrária paulista (1700-1836). São Paulo: Hucitec, 2000.

MORAES SILVA, A. de. Diccionario da lingua portugueza. Lisboa: Typographia Lacerdina, 1813.

NADALIN, S. O. A população do passado colonial brasileiro: mobilidade versus estabilidade. Topoi: Revista de História, Rio de Janeiro, v. 4, n. 7, p. 222-275, 2003. NAZZARI, M. O desaparecimento do dote: mulheres, família e mudança social em São Paulo, Brasil, 1600-1900. São Paulo: Companhia das Letras, 2001.

OLIVEIRA, A. J. M. de. Devoção e caridade: irmandades religiosas no Rio de Janeiro imperial (1840-1889). Dissertação (Mestrado em História - Instituto de Ciências Humanas e Filosofia, Universidade Federal Fluminense, Niterói, 1995.

OLIVEIRA, M. I. C. O liberto: o seu mundo e os outros, Salvador, 1790-1890. Salvador: Corrupio, 1979.

PATTERSON, O. Slavery and social death: a comparative study. Cambridge: Harvard University Press, 1982.

PINHEIRO, C. C. Quereis ser escravo?: escravidão, saberes de dominação e trajetórias de vida na cidade do Rio de Janeiro, 1808-1865. Dissertação (Mestrado em Antropologia Social) - Museu Nacional. Universidade Federal do Rio de Janeiro, Rio de Janeiro, 1998.

POLANYI, K. A grande transformação: as origens de nossa época. 4. ed. Rio de Janeiro: Campus, 2000.

REIS, J. J. Domingos Sodré, um sacerdote africano: escravidão, liberdade e candomblé na Bahia do século XIX. São Paulo: Companhia das Letras, 2008.

SAINT-HILAIRE, A. de. Viagem à provincia de São Paulo. Tradução de Regina Regis Junqueira. Belo Horizonte: Itatiaia, 1976.

SCHWARTZ, S. B. Segredos internos: engenhos e escravos na sociedade colonial, 1550-1835. São Paulo: Companhia das Letras, 1988. 


\section{Roberto Guedes}

SLENES, R. W. Senhores e subalternos no oeste paulista. In: ALENCASTRO, L. F. de (Org.). História da vida privada no Brasil. São Paulo: Companhia das Letras, 1997. v. 2, p. 233-290.

SOARES, M. de S. Fortunas mestiças: perfilhação de escravos, herança e mobilidade social de forros em Campos dos Goitacases no alvorecer do Oitocentos. Revista Estudos de História, Franca, v. 9, n. 2, p. 165-194, 2002.

- A dádiva da alforria e o governo dos escravos no Brasil colonial (Campos dos Goytacazes, c. 1750 - c. 1830). LPH: Revista de História (UFOP), v. 14, p. $165-$ 194, 2005.

- A remissão do cativeiro: a dádiva da alforria e o governo dos escravos nos Campos dos Goitacases, c. 1750 - c. 1830. Rio de Janeiro: Apicuri, 2009.

XAVIER, R. C. Religiosidade e escravidão, século XIX: mestre Tito. Porto Alegre: Editora da UFRGS, 2008.

Recebido em: 21/03/2010

Aprovado em: 30/04/2010 